\title{
Technologies in Discovery and Exploration of Fuling Shale Gas Field, China
}

\author{
Xusheng Guo, Dongfeng Hu, Yuping Li, Xiangfeng Wei, Qingbo Wang, Hui Zhang \\ Exploration Company, SINOPEC, Chengdu, China \\ Email: 173102997@qq.com
}

Received 30 March 2016; accepted 27 May 2016; published 30 May 2016

Copyright (C) 2016 by authors and Scientific Research Publishing Inc.

This work is licensed under the Creative Commons Attribution International License (CC BY). http://creativecommons.org/licenses/by/4.0/

(c) (i) Open Access

\begin{abstract}
Marine shale gas in South China is widely distributed and demonstrates an enriched resource. Compared with the North American commercial shale gas field, the shale formation in South China is featured by old age, multiple stages tectonic movements, and high thermal evolution degree and complex reservoir forming conditions. As a result, the existing theories and technical methods of exploration in North America cannot be simply applied to South China. Since 2007, based on the in-depth study on a large quantity of analytical test data, we have conducted the theory and technology research for the southern marine shale gas, found Wufeng-Longmaxi Group deep water shelf high-quality shale gas critical parameters coupling laws, proposed the "Binary Enrichment" theory for highly evolved marine shale gas in southern complex tectonic zone, and established a zone selection and evaluation criteria, which are based on the quality of shale, for the key of preservation condition, and for the purpose of economy. Taking this as a guide, we selected Longmaxi formation Lower Silurian of Fuling area in southeastern Sichuan Province as the preferred breakthrough field for the shale gas exploration. The Jiaoye 1 well has the daily gas production of $20.3 \times$ $10^{4} \mathrm{~m}^{3}$, which embarked the found of China's first large-scale business development gas field, the Fuling shale gas field. And we submit the first domestic shale gas proven reserves of $1067.5 \times 10^{8}$ $\mathbf{m}^{3}$. The Fuling shale gas reservoirs are deep water shelf marine high-quality shale, with favorable thickness and even distribution, without dissection in the middle. They are typical self-generation and self-storage shale gas reservoirs. The gas fields have high production gas well; high pressure gas reservoir, good gas components and good exploit results, and there for the Fuling shale gas field is characterized by mid-depth, high pressure, high reservoir pressure, and high quality gas accumulation. Up to March 24, 2014, all of the 101 fracture-gas testing wells have obtained middle and upper shale airflow, with the average single well test production of $32.6 \times 10^{4} \mathrm{~m}^{3} / \mathrm{d}$. In the exploration and development process, technology series in geological evaluation, horizontal well, drilling, well completion, piecewise fracturing techniques have been gradually formed. It is of great importance to commercially develop the domestic shale gas and promote the restructuring of China's energy structure.
\end{abstract}


Keywords

Exploration Discovery, Key Technologies, Shale Gas, Wufeng-Longmaxi Group, Fuling Shale Gas Field

\section{Introduction}

United States is the first country who successfully extracted shale gas. In 1992, the first horizontal well was drilled in the Barnett shale gas field using modern drilling technology. For the next 20 years, the exploration and development patterns and techniques were popularized in North America. In 2013, the annual production of shale gas in United States reached 310 billion, which exceeded the total natural gas output in China. Since the $21^{\text {st }}$ century, attention was gradually paid to domestic shale gas research and exploration practice. Although a series of supporting policies was made, but early exploration results were not satisfactory, and it is still a long way to go to large scale commercial development.

The exploration of marine shale gas in South China is current focus. However; shale-gas enrichment of hydrocarbon exploration in China is in the early stages, with complex technical and theoretical problems unsolved. 1) In contrast to commercial shale gas field in North America, the marine shale gas fields in South China are characterized as old age, high and complex tectonic evolution; 2) lack of available theoretical guidance and appropriate evaluation methodologies. The evaluative criteria of shale gas in North America are not applicable while evaluation system for south complex structure and mountain terrain has not been established yet; 3) technology and equipment are restricted. There are no available technology and equipment for multi-stage fracturing in the market; 4) the early south marine shale gas exploration is without effective breakthrough. It is still uncertain whether it is possible to find gas field under complicated geological condition in south China. It was reported that five exploration wells, Liye 1, Enye 1, Longye 1, Longye 2, and Longye 3, drilled by Shell and Chevron, focusing two major shale gas formation in Silurian Longmaxi group, Cambrian Niutitang group didn't find commercial gas stream. Four wells, Xuanye 1, Heye 1, Huangye 1 and Xiangye 1, drilled in Xuancheng-Tonglu Anhui, Hunan and Hubei, southeastern Huang Ping, Hunan lianyuanblockby Sinopec, were dry except low gas stream was obtained by Huangye 1 and Xiangye 1 . All the exploration practice indicates that we cannot copy the theory and technology from North America, but develop our own evaluation criteria and exploration technology for shale gas field due to the specificity and complexity of Chinese geological settings.

\section{With Theoretical Innovation and Technology Research, We Discovered the Fuling Shale Gas Fields}

\subsection{Creatively Proposed Marine Shale Gas "Binary Enrichment" Theoretical Understanding}

China has huge shale gas resources. Inspired by North America shale gas, since 2007, China has been working on geological theory and technology method for shale gas exploration, carrying out lots of fundamental research work, reviewing Dingshan1 well, Lin 1 well, and 40 more old wells, and research on Xishui-Qilong village, Xiliao and 25 outcrop sections materials of Sichuan basin and the adjacent areas, carry out various analysis test of organic geochemistry, physical property, gas-bearing properties, rock and minerals and rock mechanics, definitude geological conditions of marine shale gas, lay the foundation for Fuling gas field discoveries.

Large solid information research makes awareness gradually clear of shale gas exploration. Shale gas Explorer proposed "Binary Enrichment" for shale gas enrichment in complex structure high evolution degree areas: 1) better of material based, i.e. "favorable deposition environment in deep surface shed", is the basic conditions for "hydrocarbon control reservoir"; 2) good preservation condition, i.e. "tight top/floor burden, and moderate buried depth, and away from opened fracture", are the key elements of "accumulation control production". The theory is a big step forward for shale gas geology, brought shale gas geology a leap and an innovation.

\subsubsection{Deep Shelf Quality Shale Is the Basis of Marine Shale Gas Accumulation with High Productivity}

Deep shelf facies, plenteous organisms and oxygen-deprived environments, developed shale with high organic 
matter. This is the good basis for organic-hole development; organic development of holes provided plenty of storage space for shale gas. In addition, the shale with high abundance of organic matter has biological, biochemical causes of high silica content, while high TOC content and high silica content had a good coupling characteristics, organic matter of which had enrichment at the same time, had good compression, created favorable conditions for crack shale gas pressure and high yield (Figures 1-4).

\subsubsection{The Good Preservation Conditions Are the Key to Marine Shale Gas Accumulation with High Productivity}

1) Established new thinking way through the hydrocarbon enrichment in early to loss in late, and of dynamic

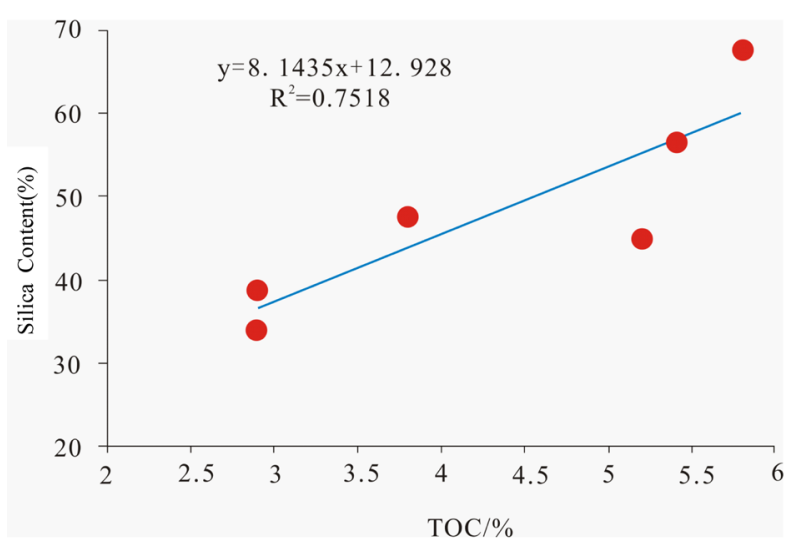

Figure 1. Positive correlation of TOC and silicon contents of deep shelf stratain shale of Long maxi Formation of Qilongcun Outcrop.

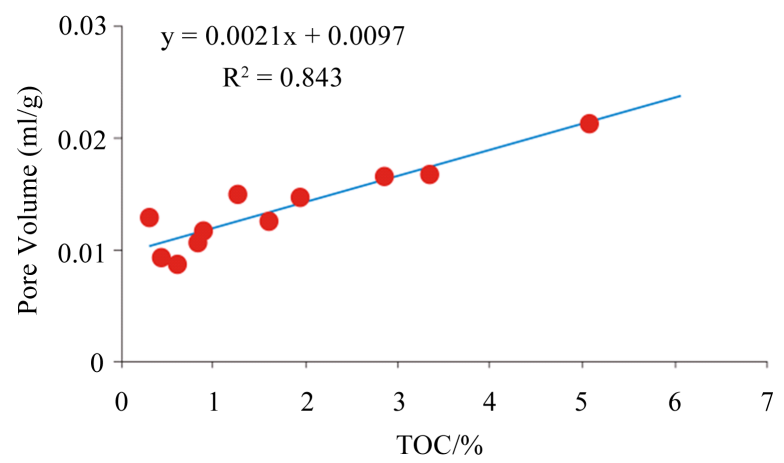

Figure 2. Positive correlation of TOC and pore volume of deep shelf strata in shale of Long maxi Formation of Qilongcun Outcrop.

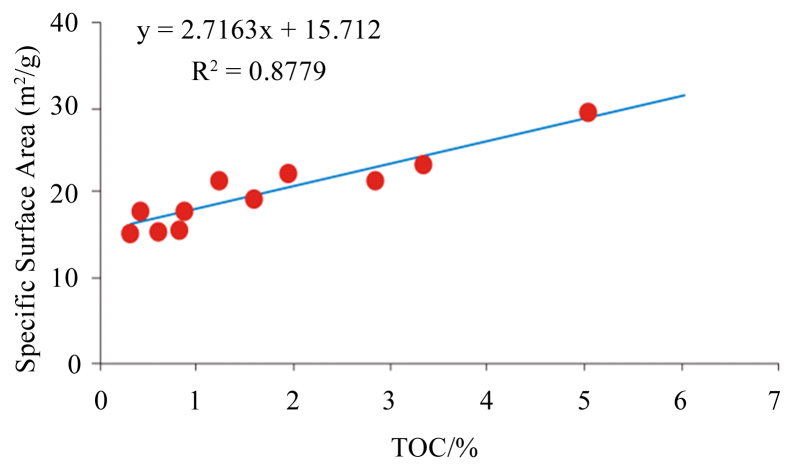

Figure 3. Positive correlation of TOC and specific surface area of deep shelf strata in shale of Long maxi Formation of Qi Longcun Outcrop. 


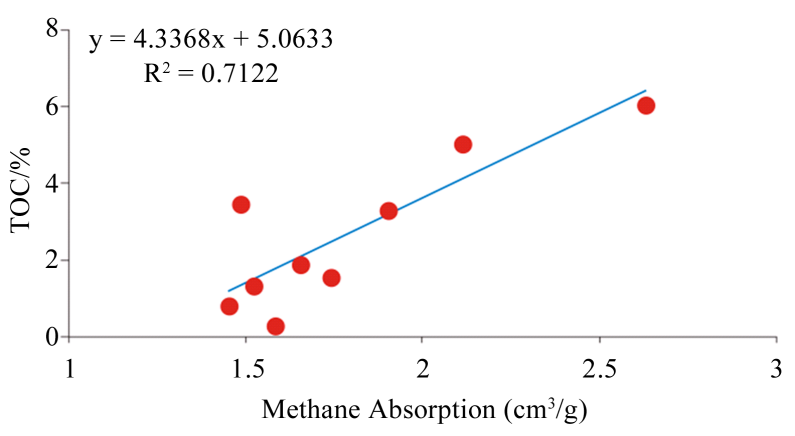

Figure 4. Positive correlation of TOC and absorbed methane of deep shelf strata in shale of Long maxi Formation of Qilongcun Outcrop.

study the effects of preservation condition.

In early continuous deep stage, organic-rich shale hydrocarbon expulsion and dynamic evolution of hydrocarbons remain. The main factors affecting retention of shale gas are the roof and floor conditions. First, they play an important role in the storage of the shale gas; on the other hand, they also influence the effect of shale fracturing. Superior roof and floor conditions are the premises of shale gas good storage conditions. In late continued uplift stage, hydrocarbon generations top, and shale gas escape. Main factor of shale gas preservation is structure effect which not only makes oil and gas stagnation, while makes covered rock and regional cover layer of containing gas shale thin or erosion, leading a smaller top covered pressure, which makes shale gas breakthrough to cover layer and up escape. The late uplift movement of Yanshan in southeast area of Sichuan province is most key time for shale gas preservation (Figure 5).

2) Latetectonic intensity and time control how shale gas escape and its abundance

Strong sustained uplift in the late stage is reconstruction phase for shale gas reservoir in which gas generation has already stopped and gas escaping already begun. Shale gas emission intensity and scale determined the abundance of shale gas. Shale gas of Wufeng-Longmaxi group in Sichuan basin and its adjacent areas has began continued uplift of starting time main in Yanshan period (Figure 5). Different structure parts exist differences, from basin outside to basin within continued uplift of starting time performance out from early till late ordered progressive of features (Figure 6). The late escape time of shale gas is the late continued uplift to the whole stage for shale gas.

3) Basin tectonic transformation is weak, while preservation conditions are relatively good

Pressure coefficient is the comprehensive index of preservation conditions, and high pressure and over pressure mean good preservation conditions. In the adjacent areas of Sichuan basin, lateral structural modification time is long, tectonic reconstruction strength is strong, uplift and erosion is strong, "Babel" faults is developed, shale-gas preservation conditions in general is poor, and significant variations in shale gas production exist in different wells (Table 1). Within the basin is mainly characterized by high pressure, Over pressure, high production; outside the basin is characterized by low pressure-pressure and low yield.

\subsection{Based on the "Binary Enrichment" Theory, the High Evolutionary in Complex Structure Area Evaluation System Was Raised}

Southern marine shale and shale gas in North America are quite different in terms of geological conditions. It is far from enough if only basic geological conditions are considered. "Preservation" is the core area of the South. So with south complex district "binary enrichment" theory guide, to full use favorable target of commercial development of shale gas, we established a set of evaluation system and standards with three big class, and 18 parameters for south sea phase shale gas (Table 2). It is more suitable for complex district like South shale gas.

\subsection{Optimized Target, Achieving Jiao Shiba of Shale Gas Exploration Major Breakthroughs}

We used marine shale constituency system as a standard, and make full use of the outcrop, drilling (logging, well-logging, well testing), seismic and test information to conduct comprehensive evaluation of exploration conditions, reliability, risk. We selected Jiao shiba, Dingshan, Nan tianhu, Lin tanchang, Pingbian, and other exploration targets. Through comparative analysis of conditions for exploration and development in different areas, 
X. S. Guo et al.

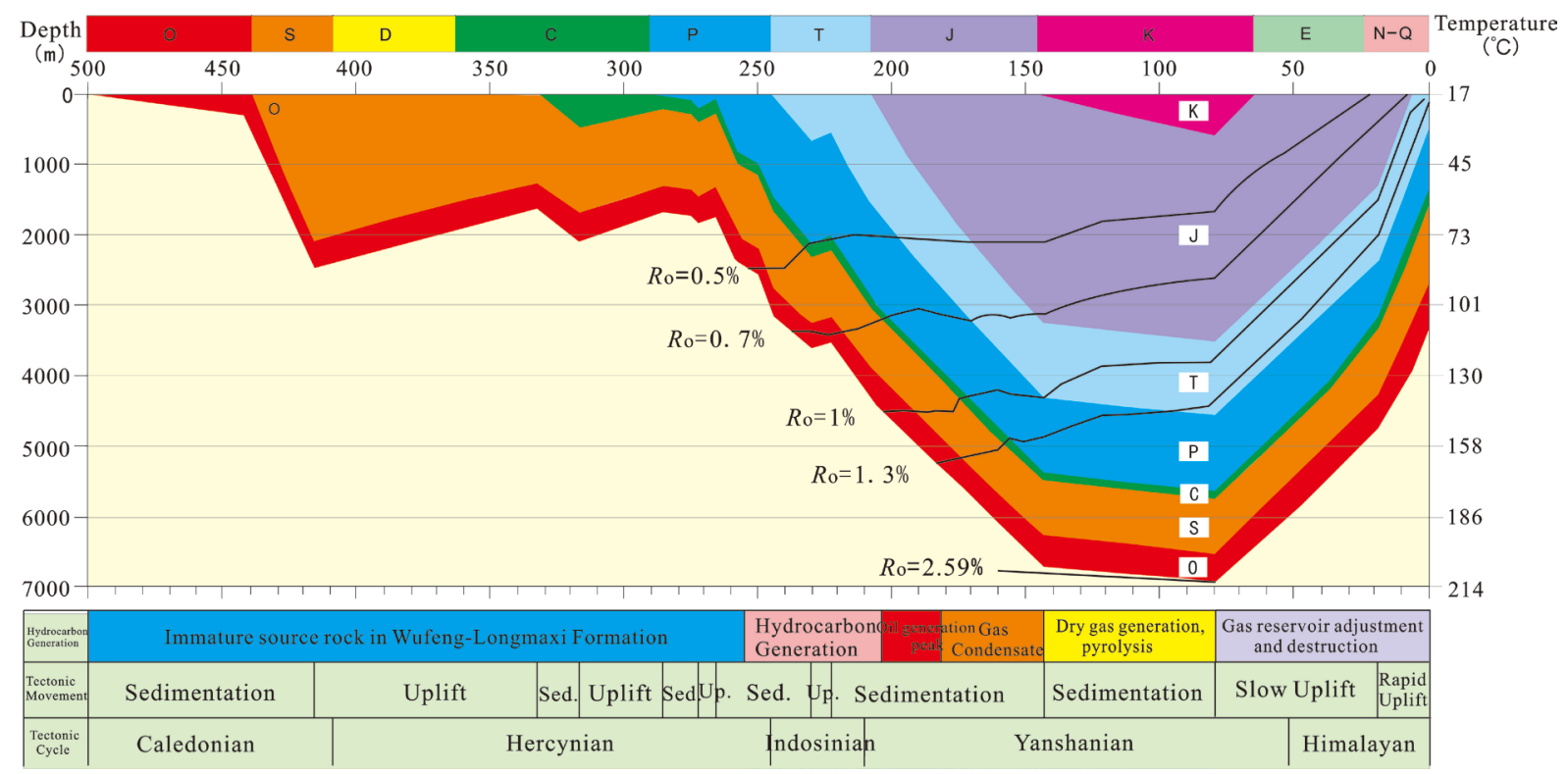

Figure 5. Bury history of Well xx1 shale gas of Wufeng-Longmaxi Formation in Sichuan Basin and its adjacent areas.
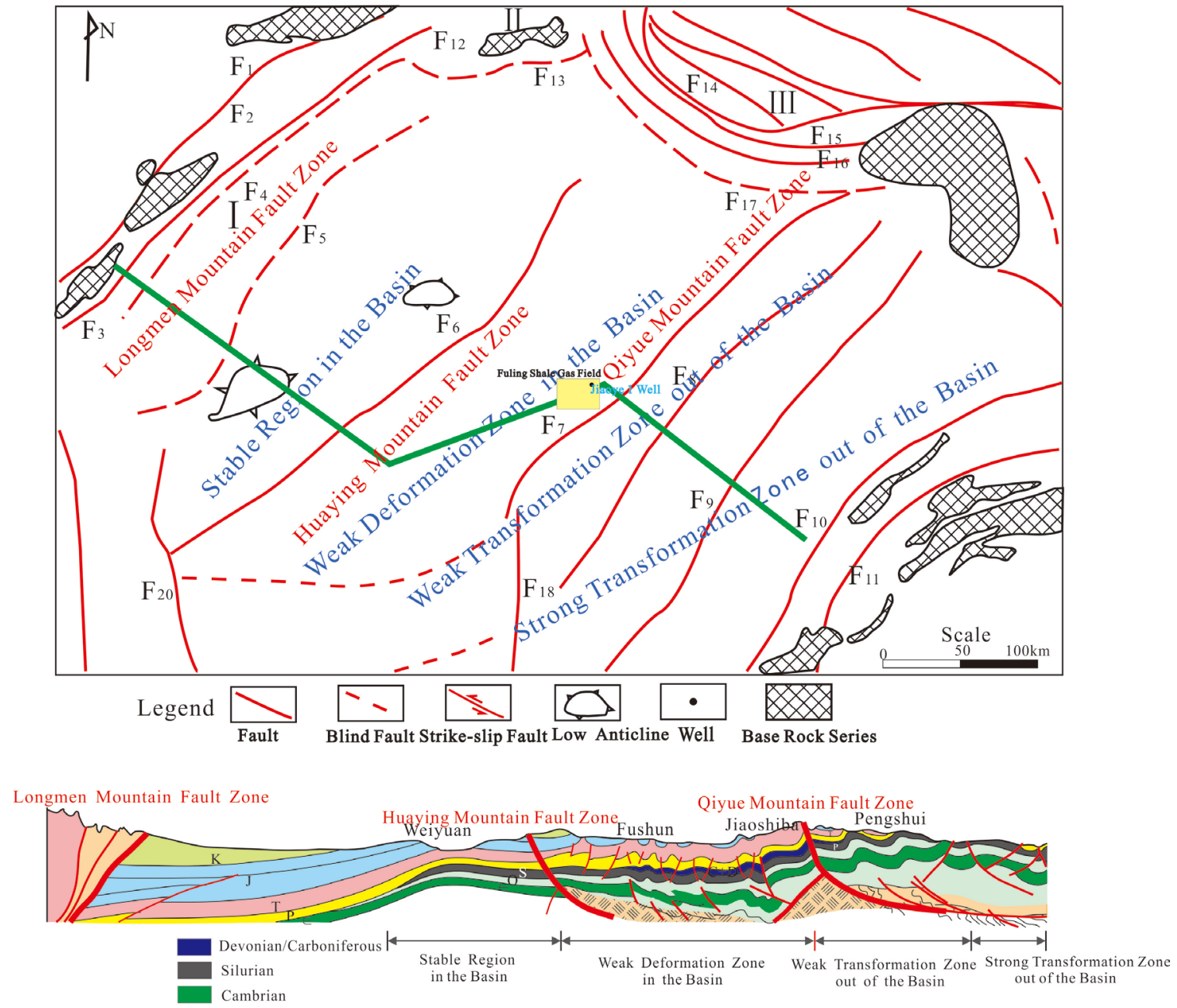

Figure 6. Structural division of Sichuan Basin and its adjacent areas. 
Table 1. Drilling shale gas preservation conditions evaluations in Sichuan basin and its adjacent areas (according to Guo xusheng, 2014).

\begin{tabular}{|c|c|c|c|c|c|}
\hline Tectoniclocation & Well number & $\begin{array}{l}\text { Gas production rate } \\
\qquad\left(10^{4} \mathrm{~m}^{3} / \mathrm{d}\right)\end{array}$ & Pressure coefficient & Gas component & $\begin{array}{c}\text { Evaluation of preservation } \\
\text { condition }\end{array}$ \\
\hline \multirow{3}{*}{ Basin } & W201-H1 & 1 & 1.0 & $\mathrm{CH}_{4}$ & $\begin{array}{l}\text { Good } \\
\text { Good }\end{array}$ \\
\hline & N201-H1 & 15 & 2.03 & $\mathrm{CH}_{4}$ & Good \\
\hline & Y201-H2 & 43 & 2.2 & $\mathrm{CH}_{4}$ & Good \\
\hline \multirow{3}{*}{ Adjacent areas } & PYHF-1 & 2.5 & $0.9 \sim 1.0$ & $\mathrm{CH}_{4}$ & Good \\
\hline & Z101 & Micro gas bearing & 0.8 & $\mathrm{~N}_{2}, \mathrm{CO}_{2}$ & $\begin{array}{l}\text { Bad } \\
\text { Bad }\end{array}$ \\
\hline & YY1 & Micro gas bearing & & $\mathrm{N}_{2}, \mathrm{CO}_{2}$ & Bad \\
\hline
\end{tabular}

Table 2. Marine shale gas in Sichuan basin and its adjacent areas evaluation form.

\begin{tabular}{|c|c|c|c|c|c|c|}
\hline \multirow{2}{*}{$\begin{array}{l}\text { Parameter } \\
\text { type }\end{array}$} & \multirow{2}{*}{ Parameter name } & \multirow{2}{*}{ Weight } & \multicolumn{4}{|c|}{ Value } \\
\hline & & & $1.0-0.75$ & $0.75-0.5$ & $0.5-0.25$ & $0.25-0$ \\
\hline \multirow{7}{*}{$\begin{array}{l}\text { Quality of } \\
\text { shale } 0.3\end{array}$} & $\begin{array}{l}\text { Thickness of } \\
\text { shale (m) }\end{array}$ & 0.1 & $>40$ & $40-30$ & $20-30$ & $10-20$ \\
\hline & TOC (\%) & 0.3 & $>4$ & $4-2$ & $2-1$ & $<1$ \\
\hline & Kerogen type & 0.1 & I & II1 & II2 & III \\
\hline & Ro & 0.1 & $1.2-2.5$ & $1.0-1.2 ; 2.5-3.0$ & $0.7-1.0 ; 3.0-3.5$ & $0.4-0.7 ; 3.0-4.0$ \\
\hline & $\begin{array}{l}\text { Brittleness } \\
\text { index (\%) }\end{array}$ & 0.3 & $>60$ & $60-40$ & $40-20$ & $<20$ \\
\hline & Physical properties (\%) & 0.1 & $>6$ & $6-4$ & $4-2$ & $<2$ \\
\hline & $\begin{array}{c}\text { Fracture } \\
\text { development }\end{array}$ & 0.2 & not developed & less developed & rather developed & developed \\
\hline \multirow{7}{*}{$\begin{array}{c}\text { Storage } \\
\text { Conditions } \\
0.4\end{array}$} & Structural styles & 0.1 & Wrinkle relief & Wrinkle with rather relief & $\begin{array}{l}\text { Wrinkle is rather } \\
\text { clench }\end{array}$ & Wrinkle clench \\
\hline & pressure coefficient & 0.4 & $>1.5$ & $1.5-1.2$ & $1.2-1.0$ & $<1.0$ \\
\hline & Cover & 0.1 & Jurassic-Cretaceous & Triassic & Permian & Silurian \\
\hline & Roof and floor & 0.2 & Extremely dense & Dense & Rather dense & Not dense \\
\hline & depth of burial (m) & 0.2 & $1500-3500$ & $3500-4500$ & $>4500 / 500-1500$ & $0-500$ \\
\hline & $\begin{array}{l}\text { Amount of resources } \\
\text { (100 million cubic) }\end{array}$ & 0.2 & $>500$ & $200-500$ & $100-200$ & $<100$ \\
\hline & $\begin{array}{c}\text { Production } \\
\left(10^{4} \text { cubic } / \mathrm{km}\right)\end{array}$ & 0.2 & $\geq 10$ & $3-10$ & $0.3-3$ & $<0.3$ \\
\hline \multirow[t]{4}{*}{$\begin{array}{c}\text { Economic } \\
0.3\end{array}$} & $\begin{array}{l}\text { Surface topographical } \\
\text { conditions }\end{array}$ & 0.1 & $\begin{array}{c}\text { Hilly area+ plain > } \\
75 \%\end{array}$ & $\begin{array}{l}\text { Hilly area+ plain } \\
50 \%-75 \%\end{array}$ & $\begin{array}{c}\text { Middle-low } \\
\text { In mountainous } \\
\text { areas }\end{array}$ & $\begin{array}{c}\text { Dominated by } \\
\text { mountains, plateaus, } \\
\text { and swamps }\end{array}$ \\
\hline & River system & 0.1 & $\begin{array}{l}\text { Development of } \\
\text { rivers, reservoirs }\end{array}$ & $\begin{array}{l}\text { Rivers is rather developed } \\
\text { and near the reservoir }\end{array}$ & $\begin{array}{l}\text { Water system is } \\
\text { only with a river }\end{array}$ & No major rivers \\
\hline & Marketing Network & 0.1 & Have pipe networks & Near pipe network & $\begin{array}{l}\text { Be to have pipe } \\
\text { network }\end{array}$ & $\begin{array}{l}\text { Market } \\
\text { is not developed }\end{array}$ \\
\hline & Traffic & 0.1 & $\begin{array}{l}\text { State, provincial } \\
\text { coverage }\end{array}$ & half provincial covers & County-level roads & $\begin{array}{l}\text { With inconvenient } \\
\text { transportation }\end{array}$ \\
\hline
\end{tabular}


we further propose Long maxi Group Silurian Fuling southeast Sichuan as efficient an exploration of shale gas, which deploys recommendations for exploration.

Regional studies have shown that the quality of shale in Long maxi Group Jiao shiba area is characterized as high quality thickness of $30-48 \mathrm{~m}$, thermal evolution is in the $2.5 \%$, type I of organic matter, brittle mineral content of mineral components up to $50 \%$. In terms of preservation conditions: structural position is located in the eastern part of the Sichuan basin in East Sichuan Ejective fold belt, West of the basin boundary breaking, and is a special structure of Wanxian synclinorium. Unlike its both sides of the north-east or near south-north Narrow high and steep anticline, Jiao shiba constructs are as box-shaped anticline structure, body region smooth, weak deformation and fault is not developed [1]-[19] (Figure 7). In terms of economic aspects: buried at the depth of 2000 - $3500 \mathrm{~m}$, large resources, surface condition is the plains and hills, water conditions are good, and easy to large-scale fracturing and development of shale gas. It is defined as Class I target and shale gas breakthrough objective based on comprehensive evaluation, with good shale gas geological conditions, engineering specification, and affordability. Based on the above, the September 2011 in Jiao shiba construction district, we deployed the Well Jiaoye 1.

On November 28, 2012, the gas testing of Well Jiaoye $1 \mathrm{HF}$ received $0.3 \times 10^{4} \mathrm{~m}^{3}$ daily gas production, marine shale gas exploration in South China made significant breakthroughs. By March 2015, the production of Fuling shale gas field has continued to increase steadily, cumulative shale gas production has exceeded $15 \times 10^{8}$ $\mathrm{m}^{3} .101$ shale horizontal wells in gas fields has been put into trial production in Fuling shale gas field, gas production of which is about $500 \times 10^{4} \mathrm{~m}^{3} / \mathrm{d}$, with an average production of single well of $50 \times 10^{4} \mathrm{~m}^{3} / \mathrm{d}$. Jiaoye $1 \mathrm{HF}$ well, by March 3, 2015, after 2 years of pilot production, its production and pressure is stable, with production

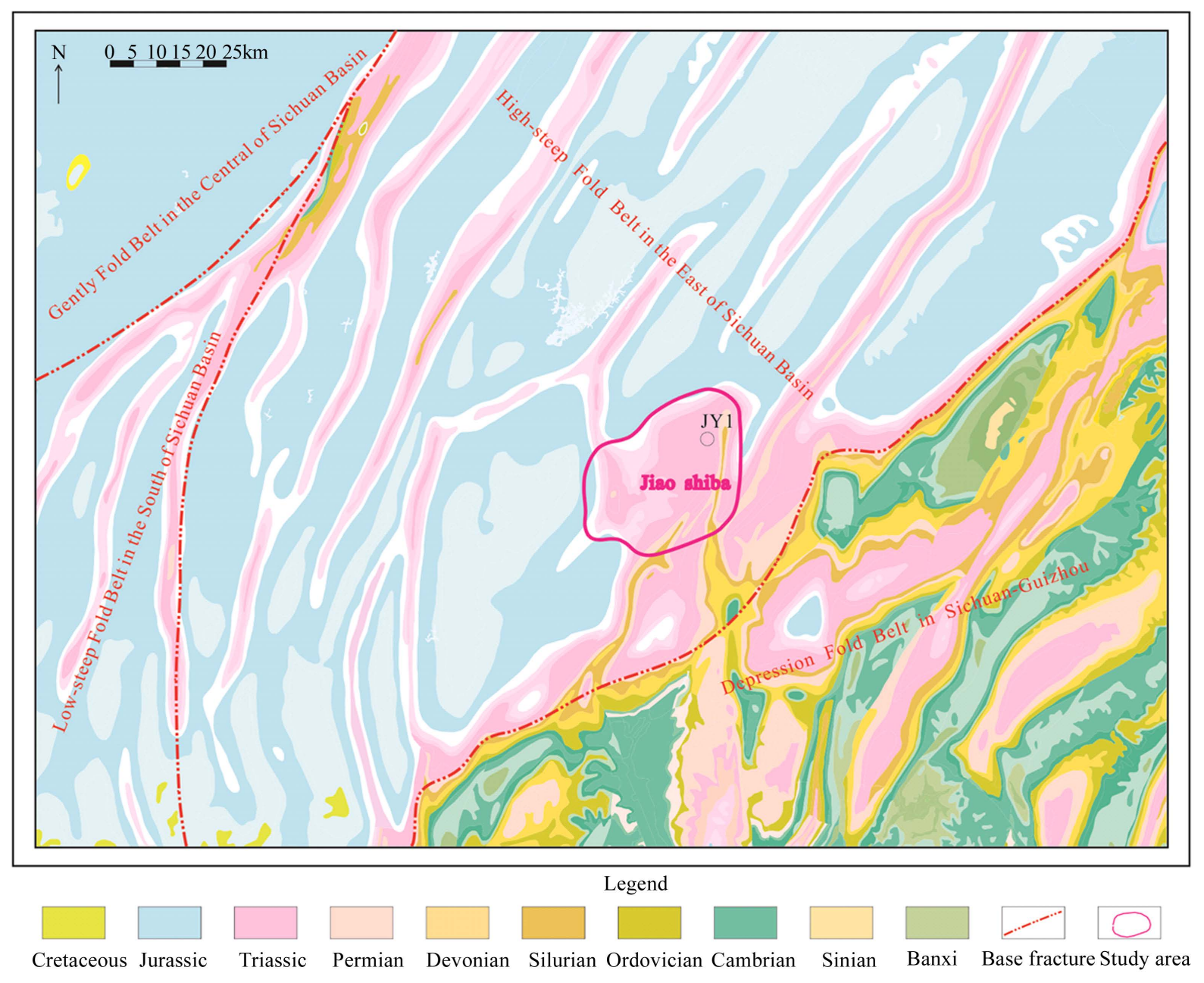

Figure 7. The structure location of Jiaoshiba area (modified from Guo Xusheng, 2014). 
higher than $6.0 \times 10^{4} \mathrm{~m}^{3} / \mathrm{d}$ (Figure 8), cumulative gas production $5292.9589 \times 10^{4} \mathrm{M}^{3}$, oil pressure, and casing pressure stable in $12 \mathrm{MPa}$ above, of which Jiaoye 6 - 2 well production is highest, currently daily gas production is in $20 \times 10^{4} \mathrm{M}^{3}$ above, and its pressure and production is stable, has cumulative produced gas $1.4430 \times 10^{8} \mathrm{~m}^{3}$. In exploration development process of gas field, shale gas exploration technology series were preliminarily formed: firstly, in theory research aspects, we make clear marine shale gas enrichment mechanism and high yield controlling factors; secondly, in earth physical technology evaluation and forecast aspects, we formed fast qualitative recognition measuring well integrated evaluation technology and seismic integrated forecast technology [9] [10]; thirdly, we formed shale gas drilling and completion well key technology.

\subsection{Geological Characteristics of Gas Field}

Sichuan basin Southeast area belongs to the deep-shallow shelf sedimentary environments. Regional deposition has a larger thickness of dark rich organic matter mud shale [13]. The graptolite class biological type is most flourish, and consequent bedding enrichment stratification; we can see more siliceous radiolarian fossils in graptolite shale in the bottom of Long maxi group deep shelf faces, with concentration gradually decreasing from bottom to top. Longitudinal upper part of Long maxi group is main for a near shore shallow grey, grey silt-bearing mudstone, and central developed a shallow shelf facies grey-deep grey mudstone and the sheet siltstone, and silt-bearing mudstone, lower for a deep shelf dark grey-black carbon graptolite shale, and carbonbearing silty mudstone, and containing spicule radiation insect pen stone shale [4]-[6]. Drilling results fromJiaoye1 well and other 4 wells showed that, the rich organic matter of mud shalein Jiao shiba area is located in lower Long maxi group, the plane distribution is stable, the thickness is between $80-120 \mathrm{~m}$; the quality mud shale is located at the bottom of Long maxi Group shale, the thickness is between 38 - $44 \mathrm{~m}$ (Table 3), the high quality rock is charactered by pure of lithology, little siltstone, high carbonaceous component, enrichment of graptolite, and development of lamellation joint.

According to the Jiaoye 1 well test results of core sample analysis, the shale of Wufeng-Longmaxi Formationare charactered by high TOC content, well organic matter type, moderate degree of thermal evolution, high brittle mineral, good physical property, high gas content (Table 3, Figure 9). TOC content in $0.55 \%-5.89 \%$, average value of $2.54 \%$, type I of organic matter, Ro in $2.42 \%-2.80 \%$, average value of $2.59 \%$, at a over-mature stage, and natural gas is mainly dry gas. X-ray diffraction analysis shows that brittle mineral contents are between $33.9 \%$ - $80.3 \%$, with an average of $56.5 \%$, dominated by silica minerals, with $37.3 \%$ on average;
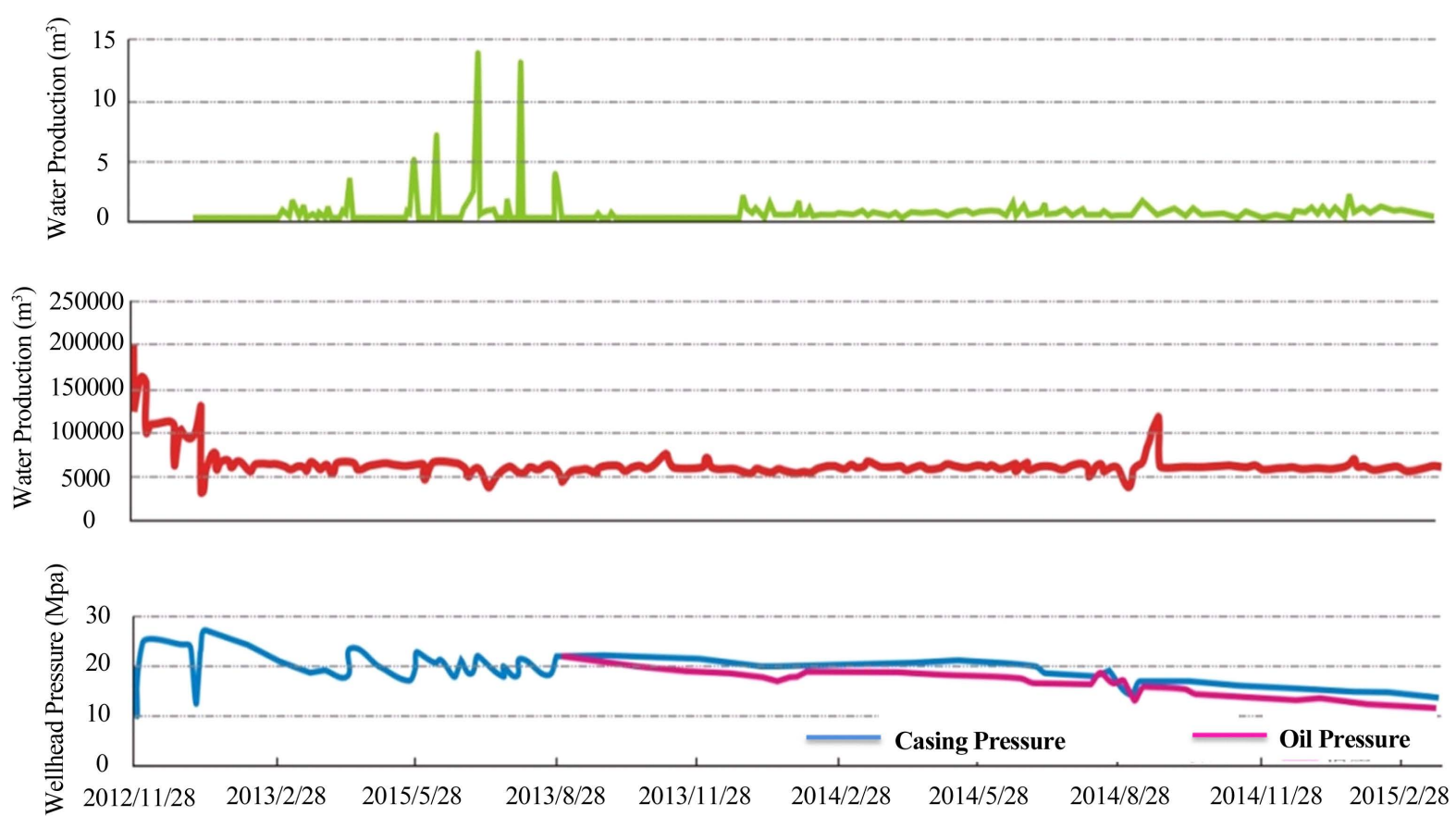

Figure 8. Shale gas production testing curve in Wufeng-Longmaxi Formation of Jiaoye 1HF well. 
Table 3. Analysis and comparison table of test data about thickness, gas content, oil and gas shows of the shale gas reservoirs in Wufeng-Longmaxi Formation of Jiaoye 1 - 4 wells in Fuling region.

\begin{tabular}{|c|c|c|c|c|c|c|c|}
\hline $\begin{array}{c}\text { Well } \\
\text { number }\end{array}$ & Gas layer & $\begin{array}{c}\text { Well } \\
\text { section/(m) }\end{array}$ & $\begin{array}{l}\text { Thickness } \\
\text { /(m) }\end{array}$ & $\begin{array}{c}\text { Gas analysis/average } \\
\left(\mathrm{m}^{3} / \mathrm{t}\right)\end{array}$ & $\begin{array}{l}\text { Total air content/ } \\
\text { average }\left(\mathrm{m}^{3} / \mathrm{t}\right)\end{array}$ & $\begin{array}{l}\text { Drilling } \\
\text { fluid density/ } \\
\left(\mathrm{g} / \mathrm{cm}^{3}\right)\end{array}$ & $\begin{array}{l}\text { (Show thickness/ } \\
\text { m)/layers (/m) }\end{array}$ \\
\hline \multirow[b]{2}{*}{$\begin{array}{l}\text { Jiaoye } 1 \\
\text { well }\end{array}$} & Shale gas reservoirs & $2326-2415$ & 89 & $0.36-1.58 / 0.90$ & $1.52-8.85 / 4.30$ & \multirow[b]{2}{*}{$1.37-1.42$} & \multirow[b]{2}{*}{$73 / 3$} \\
\hline & $\begin{array}{c}\text { High quality shalegas } \\
\text { reservoirs }\end{array}$ & $2377-2415$ & 38 & $0.60-1.58 / 1.01$ & $3.52-8.85 / 6.03$ & & \\
\hline \multirow{2}{*}{$\begin{array}{c}\text { Jiaoye } 2 \\
\text { well }\end{array}$} & Shale gas reservoirs & $2477-2575$ & 98 & $0.18-1.21 / 0.68$ & $1.94-8.90 / 5.06$ & \multirow[b]{2}{*}{1.40} & \multirow[b]{2}{*}{$87 / 6$} \\
\hline & $\begin{array}{c}\text { High quality shalegas } \\
\text { reservoirs }\end{array}$ & $2533-2575$ & 42 & $0.83-1.21 / 0.96$ & $4.41-8.90 / 6.46$ & & \\
\hline \multirow[b]{2}{*}{$\begin{array}{l}\text { Jiaoye } 3 \\
\text { well }\end{array}$} & Shale gas reservoirs & $2313-2414$ & 101 & $0.14-1.78 / 0.73$ & $0.63-9.63 / 4.12$ & \multirow[b]{2}{*}{$1.38-1.41$} & \multirow[b]{2}{*}{$101 / 2$} \\
\hline & $\begin{array}{c}\text { High quality shalegas } \\
\text { reservoirs }\end{array}$ & $2370.5-2414$ & 43.5 & $0.54-1.78 / 1.20$ & $4.08-9.63 / 6.23$ & & \\
\hline \multirow{2}{*}{$\begin{array}{c}\text { Jiaoye } 4 \\
\text { well }\end{array}$} & Shale gas reservoirs & $2512-2595$ & 83 & $0.34-1.38 / 0.87$ & $1.19-8.83 / 4.83$ & \multirow[b]{2}{*}{$1.28-1.40$} & \multirow[b]{2}{*}{$53 / 2$} \\
\hline & $\begin{array}{l}\text { High quality shalegas } \\
\text { reservoirs }\end{array}$ & $2557-2595$ & 38 & $0.80-1.38 / 1.03$ & $4.12-8.83 / 5.93$ & & \\
\hline
\end{tabular}

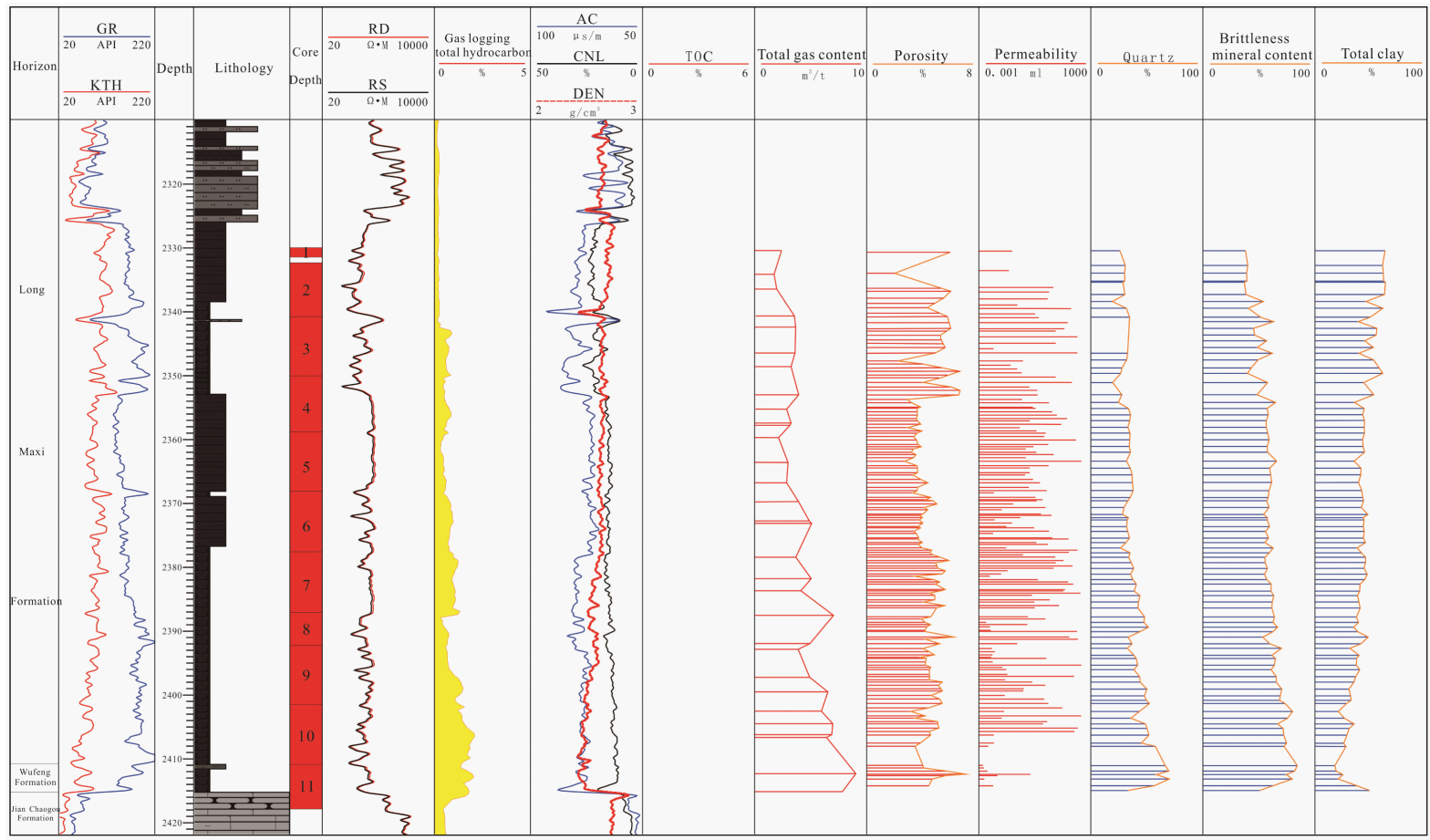

Figure 9. Theshale comprehensive histogram for Jiaoye 1 well of Wufeng Formation-Longmaxi Formation in Fuling.

Secondly dominated by plagioclase and dolomite, averages of which are $7.15 \%$ and 6.16\%; Other ingredients are less than 5\%; clay content are generally low, with dwindling features from top to bottom, vertical brittle mineral content change with "reverse symmetry" features, with content from $16.6 \%-62.8 \%$, an average of 40.9\%. Reservoir porosity is between $1.17 \%-7.22 \%$, average is $4.52 \%$; Permeability is $0.0015-335.2092 \times$ $10^{-3} \mu \mathrm{m}^{2}$, and the average is $0.65 \times 10^{-3} \mu \mathrm{m}^{2}$. Total gas production in Jiaoye 1 well is between $3.52-8.85 \mathrm{~m}^{3} / \mathrm{t}$, average $5.85 \mathrm{~m}^{3}$. Gas content distribution of 4 wells total are in the $3.52-9.63 \mathrm{~m}^{3} / \mathrm{t}$, and average is above 6.0 $\mathrm{m}^{3} / \mathrm{t}$.

Fuling gas field is the typical self-production and self-storage, continuous, mid-deep formation, and low geothermal gradient, high pressure gas reservoir. Average buried deep in the medium gas units is $2645 \mathrm{~m}$, and average geothermal gradient is 2.83 degree/100 m, and the pressure factor is 1.55 (Table 4). Dominated gas 
Table 4. Statistics on pressure and temperature of shale gas of Wufeng-Longmaxi Formation in Fuling Shale gas field.

\begin{tabular}{cccccc}
\hline Well number & $\begin{array}{c}\text { the medium of gas } \\
\text { reservoir } /(\mathrm{m})\end{array}$ & $\begin{array}{c}\text { Formation } \\
\text { pressure/(MPa) }\end{array}$ & $\begin{array}{c}\text { Pressure } \\
\text { coefficient }\end{array}$ & $\begin{array}{c}\text { Formation } \\
\text { temperature } /\left({ }^{\circ} \mathrm{C}\right)\end{array}$ & $\begin{array}{c}\text { Geothermal } \\
\text { temperature } /\left({ }^{\circ} \mathrm{C} / 100 \mathrm{~m}\right)\end{array}$ \\
\hline Jiaoye 1 well & 2645 & 40.22 & 1.55 & 89.85 & 2.83 \\
\hline
\end{tabular}

composition is methane, content of which is $97.22 \%-98.41 \%$, with low carbon dioxid, content of which is $0 \%$ 0.374\%; containing no hydrogen sulfide. It is characterized as top-quality dry gas reservoirs (Table 5).

\section{Geological Evaluation of Technology}

\subsection{Quick Identification and Quantification of Shale Gas Logging Interpretation and Evaluation Techniques}

By enhancing investigations on geochemical parameters, reservoir parameters, logging information and rock physics keeping up with the trends of international logging technique, based on "Six Property" relationship in shale reservoir, we established integrated logging assessment technology series for marine shale gas exploration and development in the south of China [10].

Application of "method of substitution" can quickly identify quality shale, and form rapid qualitative identification techniques. Marine quality shale gas have the "four high-three low” logging response, which are charactered by high GR, high enrichment uranium, high interval transit time, high resistivity ratio and low density, low neutron and gamma ray without uranium. Thorium potassium (TH-K) stack collection can be used to qualitatively recognize clay minerals: the more separation of the two, the higher the clay mineral content. The thorium uranium ratio can be used to classify deposition environment: less than 2 indicates strong restore environment, 2 - 4 indicates half restore-strong restore environment; the lithology density value divided rich organic matter shale layer section, is less than $2.6 \mathrm{~g} / \mathrm{cm}^{3}$ for rich organic matter shale layer section; uranium (U) value divided rich organic matter shale layer section, is greater than $6 \mathrm{ppm}$ for rich organic matter shale layer section.

By applying petro physical properties volume models, and statistical methods, we established explanation models for mineral components and contents, physical parameters, chemical parameters, gas content parameters, geomechanics parameters under geological constraints. Well logging has high precision in quantitative evaluation (Figure 10, Figure 11), with the organic carbon content of accuracy of 92\%, gas content accuracy of $93.9 \%$. It has an important support role for exploration and production.

We established model for mineral content and porosity models based on element capture logging (ECS) and the mixed matrix density. For complex mineral composition and pore structure of shale gas reservoir, the research innovatively proposed new method to calculate the mineral content and porosity, which improved interpretation accuracy, and formed shale gas reserves of well logging fine interpretation and calculation support. Based on elements capture logging (ECS) to calculate the mineral content, mixed grain density porosity and high precision, the relative error is between-7.6\% - $1.43 \%$.

\subsection{Seismic Prediction Technologies for Sweet Spot of Shale Gas}

Unlike conventional oil and gas reservoirs, shale gas has its own characteristics and geophysical parameters of low sensitivity of reservoirs. After obtaining major breakthroughs of shale-gas exploration in Jiaoye 1 well, Sinopec for the first time had long-spread wide-azimuth high-coverage of three-dimensional seismic data acquisition of shale gas in 2013, covering an area of $600 \mathrm{~km}^{2}$. Through the acquisition, processing and interpretation, it formed a shale gas field evaluation of seismic exploration technology. For seismic prediction technologies for sweet spot of shale gas, we generated "five parameters" of seismic prediction technologies for sweet spot of shale gas forecast technology based on long-spread wide-azimuth pre-stack density inversion technology [9]. We carried out focused research on TOC content, thickness of shale, pressing-ability evaluation, gas content, fracture prediction and so on of marine facies shale gas, effectively for ecastedzones with high quality fracturing and where fractures developed, providing strong support for the exploration development and well deployment.

In terms of TOC forecast technology, based on rock physical and the geochemical parameters analysis, we established forecast model based on rock density (Den) of total organic carbon (TOC): TOC = axDen + b; developed forecast technology based on general elastic inversion of pre-stack density prediction technology, calculate the density data volume, then according to total organic carbon forecast model to quantitatively forecast 


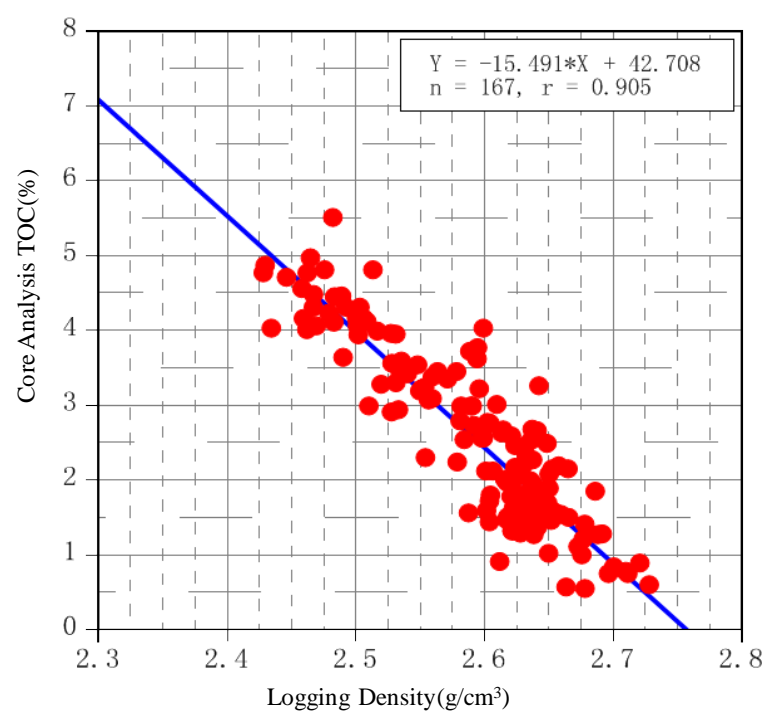

Figure 10. Crossplot of TOC by core analyses and density by logging.

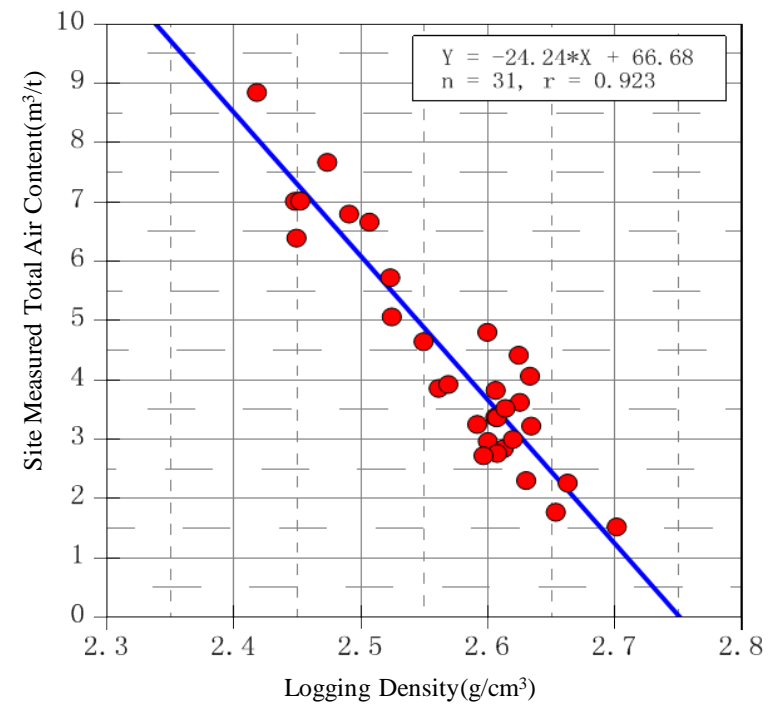

Figure 11. Crossplot of total gas contents measured on site and density by logging.

Table 5. Gas analysis table of shale gas reservoir of Wufeng-Longmaxi Formationin Fuling Shale gas field.

\begin{tabular}{cccccc}
\hline \multirow{2}{*}{ Well number } & \multicolumn{4}{c}{ Gas component (\%) } \\
\cline { 2 - 6 } & Methane & Ethane & Propane & Butane & Hydrogen \\
\hline \multirow{2}{*}{$\begin{array}{c}\text { Jiaoye 1, } 3 \\
\text { well }\end{array}$} & $97.22-98.41 / 98.204$ & $0.570-0.792 / 0.677$ & $0.019-0.232 / 0.058$ & $0-0.007 / 0.042$ & $0-0.006 / 0.014$ \\
& Helium & Oxygen & Nitrogen & $\mathrm{CO}_{2}$ & Hydrogen \\
\hline
\end{tabular}

TOC. The technology TOC content forecast has relative errors less than 2\% (Figure 12).

In terms of compressibility seismic forecast technology, through mineral composition brittle index (BI) and rock mechanical features parameter (shear modulus*density $(\mu \rho)$, and lame constants*density $(\lambda \rho)$, and Young modulus (YM), and Poisson's ratio (PR)) of cross-plot analysis, we established multi-element calculation model 


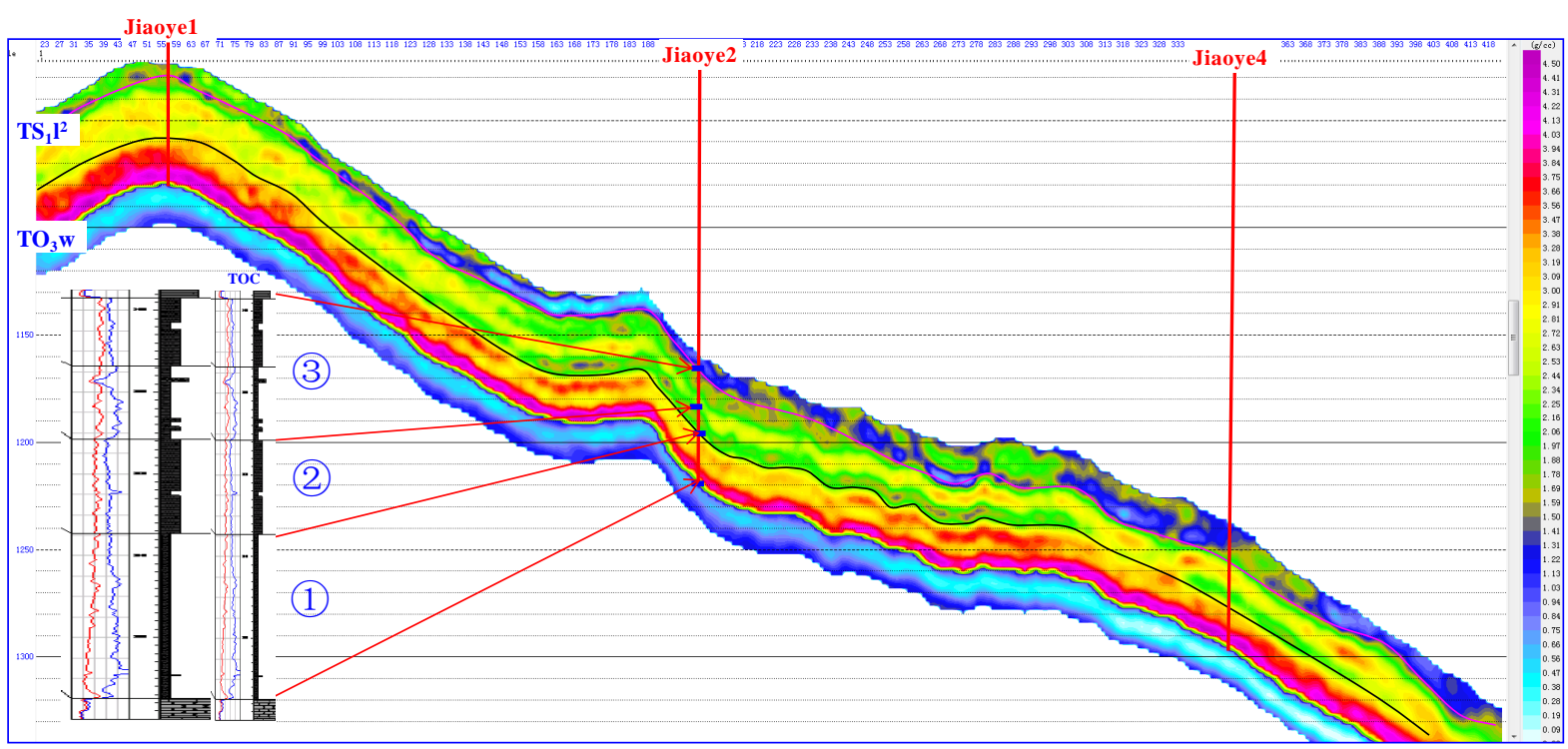

Figure 12. Sectional view of the TOC inversion through Jiaoye 1, 2, 4 well.

based on four rock mechanical features parameters of shale brittle index: $\mathrm{BI}=\mathrm{axYM}+\mathrm{bxPR}+\mathrm{Cx} \mu \rho+\mathrm{DX} \lambda \rho$ $+e$. According to more well of regression analysis, we determined coefficient: a, b, c, d, and e, and formed earthquake prediction technology basing on multi-element model of brittleness index, achieving shale section of space prediction and evaluation of compressibility, improving the accuracy of prediction of fracturing quality, providing technical support for trajectory control of horizontal well (Figure 13).

\subsection{New Methods to Identify Gas Content of High-Pressure Shale Gas Layer}

The key to calculate the total gas content of shale gas reservoir is based on reasonable regression of gas loss in field sorption method. Focusing on loss gas recovery, on account of research of both at domestic and abroad on coal bed methane simulation desorption documents, by conducting Fuling shale gas adsorption-desorption test, found high pressure deep buried shale rock solutions desorption has obviously "three-stage type" rule: when pressure just began declined, it has low desorption rate and when pressure drop to gas saturation pressure by $40 \%$ - 50\% the state of high solutions sucking rate stage, and pressure below $40 \%$ of saturation pressure, it has low desorption rate stage (Figure 14), it is found that natural gas has the highest desorption rate in the drilling process. Currently, the most commonly used linear regression method does not match the desorption rule for shale with high pressure and large buried depth, so the study established the Fuling polynomial regression loss recovery method (Figure 15). Through analysis of foreign comparative test examples, this approach is closer to holding core test gas.

3.4 Shale gas reserves calculation method

Calculating method of shale gas include static and dynamic types. Based on currently containing gas determine of two species methods (site determination total containing gas; using isothermal adsorption test determine single molecular layer adsorption gas and containing gas saturated, and porosity, and rock density, and volume coefficient calculation formula determine free gas), through research we have formed two types ofstatical calculation methods and the key parameter determine method, in domestic first carried out shale gas reserves calculation work. The new methods revealed similar results with dynamic geological reserves estimates method, reserves calculation parameter and the method are widely recognized by evaluation team. 1) Volume calculation method of estimated total reserves of gas adsorption and free gas: $\mathrm{Gz}=0.01$ Agh $\rho \mathrm{y} \mathrm{Cz}$, estimating the adsorption gas reserves: $\mathrm{Gx}=0.01$ Agh $\rho \mathrm{y} \mathrm{Cx} / \mathrm{Zi}, 2)$ Volumetric method, estimation of free gas reserves: $\mathrm{Gy}=0.01$ Agh PHI Sgi/Bgi, shale gas reserves Gz:Gz = Gx + Gy. Type in the: Gz, shale gas total geological reserves, $10^{8}$ $\mathrm{m}^{3}$; Gx, shale gas adsorption gas geological reserves, $10^{8} \mathrm{~m}^{3} ; \mathrm{Gy}$, shale gas free gas geological reserves, $10^{8} \mathrm{~m}^{3}$; Ag, containing gas area, $\mathrm{km}^{2}$; h, effective thickness, $\mathrm{m} ; \rho y$, page rock quality density, $\mathrm{t} / \mathrm{m}^{3}$; $\mathrm{Cz}$, shale total containing gas, $\mathrm{m}^{3} / \mathrm{t}$; $\mathrm{Cx}$, shale adsorption gas content, $\mathrm{m}^{3} / \mathrm{t} ; \mathrm{Zi}$, original gas deviation coefficient, no for times; $\phi$, effective pore degrees, \%; Sg, original containing gas saturated degrees, \%; Bgi, the original volume coefficient 


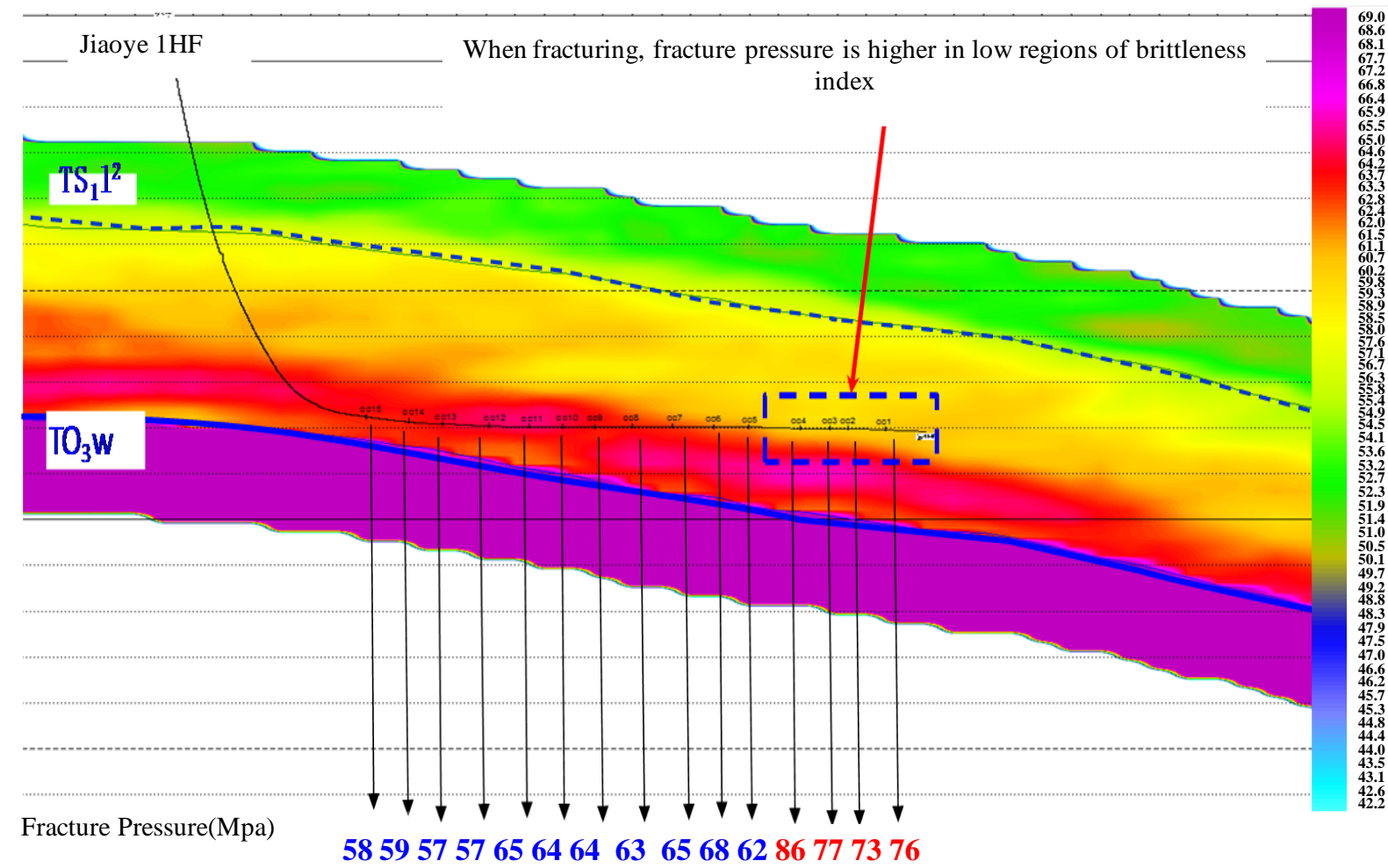

Figure 13. Brittleness index forecast map of Jiaoye 1HF Wufeng Formation-Longmaxi Formation.

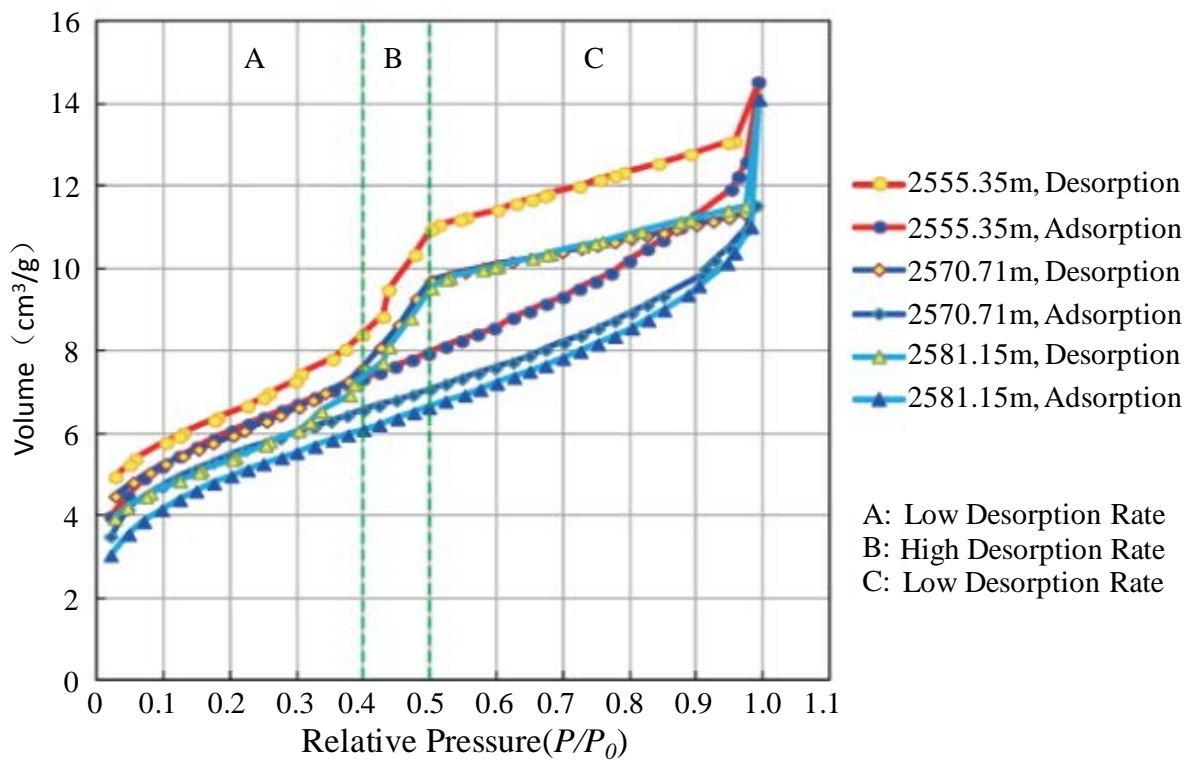

Figure 14. Absorbing and desorbing curves of shales in $1^{\text {st }}$ Section of Wufeng-Longmaxi Formation in Well Jiaoye 4 well.

of shale gas.

\section{Drilling and Completion Technology}

Both of surface and underground geologic conditions of Marine shale in Fuling district are complicated, and a set drilling and completion techniques which can be used to support the exploration work effectively, was formed to match the characteristics of this region through tackling key technical problems. Shallow gas safety 


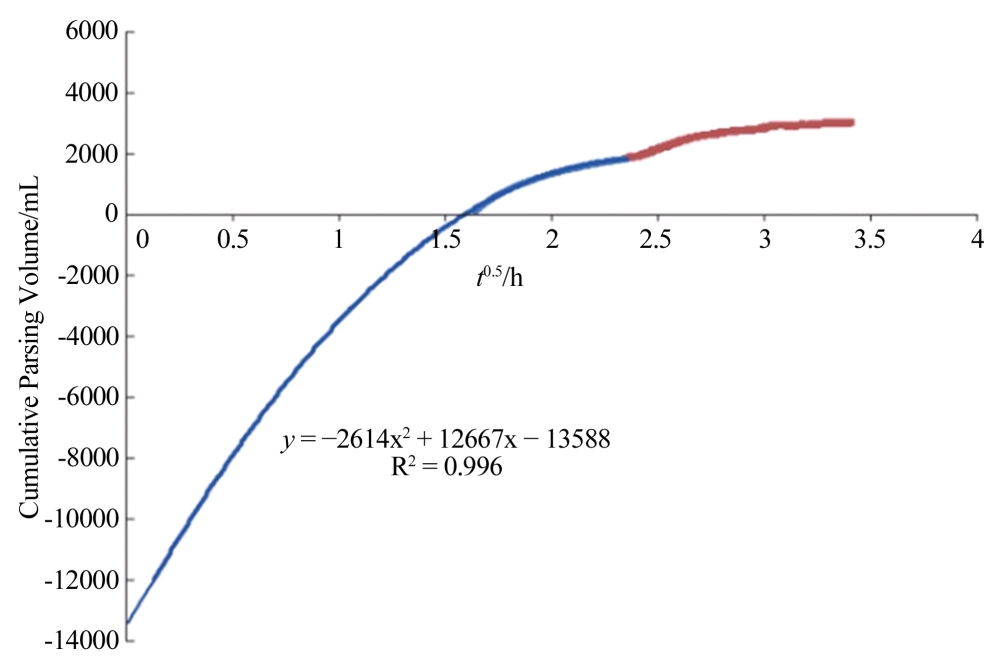

Figure 15. Model for calculating loss gas by polynomial curve regress.

drilling, gas drilling, composite drilling, horizontal well drilling, oil-based drilling fluid, elastic and plastic cement slurry system, bit selection and parameters optimization and optimized drilling technology such as geological tracking guidance are equipped with on the basis of well bore structure optimization, so as to realize the optimized drilling exploration well of this region (Figure 16). The horizontal well drilling and completion techniques of staged fracturing transformation is formed in terms of staged fracturing technology, and its goals are to increase the effective volume, complex index, and fracture diverting capacity, by the means of net pressure control, the system can carry out shale fracture crack and true tri-axial extension large size physical model experiments, and lower concentration of sanding support fracture diverting capacity evaluation experiment, so as to gain the features of shale fracture crack propagation law and diversion; formed the gliding water with "two low and three good" (low damage and low friction, good carrier, good rebound, and good configuration), "two low four good" (low damage and low friction, good sewing, good hydration, good rebound, good configuration) active rubber hydraulic fracture fluid system; formed a "3343" (3 kinds of fracturing fluids, three kinds of proppants, four kinds of discharges, three kinds of sand modes) model of fracturing. Fracturing technology above can realize the fracture network, and the control range is big, so it can provide an important guarantee of high yield and stable yield for shale airflow, and also laid a technical foundation for deep shale gas fracturing and mining technology. Compared with the north American shale gas fracturing technology, Fuling gas field fracturing technology has obvious advantages in crack length $(600 \mathrm{~m})$, and support height $(60 \mathrm{~m})$ and slippery water drag reduction rate (78\%), carrying concentration (19\%), flow-back fluid viscosity (2 maPa.s), stable production period (400 days), and other indicators.

\section{The Enlightenment That a Gas Field Was Found}

Attention to foundation, optimize selection are the precondition of shale gas exploration and discovery. It is really importance to emphasize the basic research work in exploration and discovery of southern Marine shale gas field. The potential shale gas resources in China are vast; it has many similarities with the gas-bearing shale in North America, which have been commercially developed. But it still has its own particularity. In southern China, it has experienced multiphase tectonic reworking, so the evolution degree is high and the accumulation condition is complicated. As a result, we cannot simply copy available theory and exploration technique from North America. The characteristics of shale gas from different areas and different formations should be specific on the basis of solid foundation, and the generality of the shale gas exploration and development of business that can be implemented should be summarized. Only in this way can it lays a good foundation for shale gas exploration in later stage of evaluation, and this can get twice the result with half the effort. To establish an effective evaluation standard and system, and carry out the optimization selection work are the premise of shale gas exploration and discovery. Exploration of southern marine shale gas should use shale quality as foundation, preservation conditions as core and economy as the purpose, so that we can evaluate marine shale gas in southern district more effectively, and achieve a great breakthrough of shale gas exploration. 


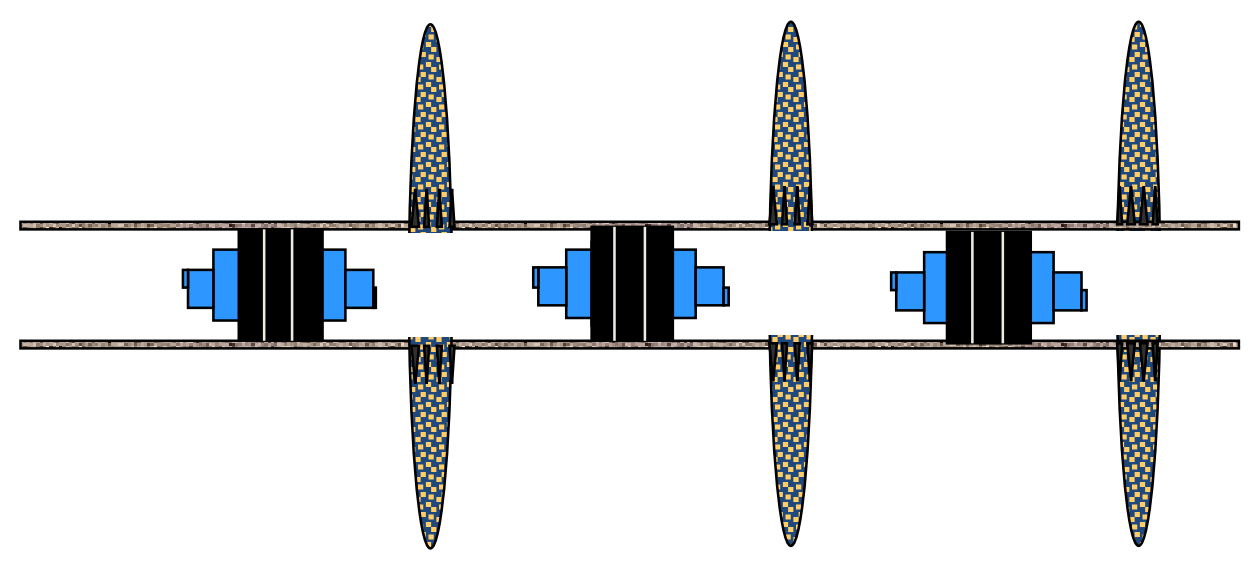

Figure 16. Wellbore schematic diagram of cable in the casing bridge plug/perforation/fracturing combination process.

Following the principles, innovation thinking is the key of shale gas exploration breakthrough. Although China is rich in shale gas reserves, its development potential is huge, and it has obtained a breakthrough in development, shale gas exploration still has to follow the basic principle of oil and gas formation. Shale gas exploration and development has its own characteristics, but shale gas exploration still needs to obey the basic rule of oil and gas formation just like conventional oil and gas, all the stages like, "generation, accumulation, caprocks, migration, gather, preservation" are essential. We have to work with innovative ideas, and establish an effective theoretical system according to the characteristics of different shale gas. Exploration breakthroughs and efficient development should focus on seizing the key scientific problems, emancipating the mind, innovating brains, developing geology, seepage flow mechanics, rock mechanics and engineering, compressed gas reservoir engineering, drilling and well completion and joint and cross research with multidisciplinary subjects, and combining scientific research with production practice closely, combining the basic theory research with technology breakthrough.

Independent innovation, development technology are the basis of shale gas efficient exploration. Hydraulic fracturing and horizontal well drilling technology are the keys to determine the costs of exploration and development technology. China still has a large gap with the United States, shale gas exploration and development cost is always high. Although development with independent technology has made a series of gratifying achievements, it's not enough compared with the need of shale gas exploration and development in our country. Therefore continue to speed up the development with independent intellectual property rights technology and key equipment development will greatly reduce the shale gas exploration and development cost, increase the efficiency of commercial development of shale gas, and make the vast area in south China commercial feasible, it will play a significant role in the development of domestic shale gas industry, and the adjustment of national energy structure.

Oil and gas exploration have no "forbidden zone", the prospect of southern area shale gas exploration is large. Oil and gas exploration workers need to have a rigorous scientific attitude and spirit of adventure. Fuling gas field region is located in the basin margin with complex region and close to the basin boundary faults. Faults development and preservation condition are complex, and it was not a promising exploration areas, but now it has become China's first large-scale shale gas field demonstration. With the development of technical theory of shale gas, we have gradually developed to deep marine, and area with more complicated structures, meantime further strengthened continental shale gas engineering technology research. Continental shale gas field has high clay content in the Yuanba region. YuanyeHF-1 well produced 7000 cubic meters of gas and 14 cubic meters daily according to the well test, and it has already been producing for more than two years stably, so far it can produce 2 - 3 ton oil and 3000 cubic meters daily. In the Dingshan region, Dingye 2 HF horizontal well was drilled at the depth of $5700 \mathrm{~m}$, with the horizontal length of $1034.23 \mathrm{~m}$, it produced $10.5 \times 10^{4} \mathrm{~m}^{3}$ shale airflow, and broke the record of deep well perforation and fracturing. It also filled the blank of shale gas fracturing construction of deep well in China. There is vast shale gas formations in the area of southern periphery, with a preliminary evaluation of shale gas geological resource showed about nearly 6 trillion cubic meters. In order to achieve a greater breakthrough, firstly, we must strengthen "Binary Enrichment" theory as the instruction, with 
emphasis on the shale gas preservation conditions to optimize and evaluate the target; secondly, we must improve to tackle key problems of engineering technology, cut the cost, increase the profits, and fulfill the commercial exploration and development. The Fuling's findings indicates that China has the geological condition to form shale gas field, and we firmly believe that with the deepening of the understanding, the progress of the theory and technology, China will make a new discovery in the other series of strata and regions.

\section{References}

[1] Guo, X.S., Guo, T.L., Wei, Z.H., Wang, W., et al. (2012) Thoughts on Shale Gas Exploration in Southern China. Engineering Sciences, 14, 101-105.

[2] Guo, X.S. (2014) Rules of Two-Factor Enrichiment for Marine Shale Gas in Southern China Understanding from the Longmaxi Formation Shale Gas in Sichuan Basin and its Surrounding Area. Acta Geologica Sinica, 88, 1209-1217.

[3] Guo, T.L. and Liu, R.B. (2013) Implication from Marine Shale Gas Exploration Break-Through in Complicated Structural Area at High Thermal Stage: Taking Longmaxi Formation in Well JY1 as an Example. Natural Gas Geoscience, 24, 643-651.

[4] Guo, T.L. and Zhang, H.R. (2014) Formation and Enrichment Mode of Jiaoshiba Shale Gas Field, Sichuan Basin. Petroleum Exploration and Development, 41, 28-36.

[5] Guo, X.S., Hu, D.F., Wei, Z.D., et al. (2014) Major Factors Controlling the Accumulation and High Productivity in Marine Shale Gas in the Lower Paleozoic of Sichuan Basin and Its Periphery: A Case Study of the Wufeng-Longmaxi Formation of Jiaoshiba Area. Geology in China, 41, 893-901.

[6] Guo, X.S., Li, Y.P., Liu, R.B., et al. (2014) Micro-Pores Structure Characteristics and Development Control Factors in Longmaxi Formation in Jiaoshiba Area. Natural Gas Industry, 34, 9-16.

[7] Hu, D.F., Zhang, H.R., Ni, K., et al. (2014) Main Controlling Factors for Gas Preservation Conditions of Marine Shales in Southeastern Margins of the Sichuan Basin. Natural Gas Industry, 34, 17-23.

[8] Wei, Z.H. and Wei, X.F. (2014) Comparison of Gas-Bearing Property between Different Pore Types of Shale: A Case from the Upper Ordovician Wufeng and Longmaxi Fms in the Jiaoshiba Area, Sichuan Basin. Natural Gas Industry, 34, $37-41$.

[9] Chen, Z.Q. (2014) Quantitative Seismic Prediction Technique of Marine Shale TOC and Its Application: A Case from the Longmaxi Shale Play in the Jiaoshiba Area, Sichuan Basin. Natural Gas Industry, 34, 24-29.

[10] Yan, W., Wang, J.B., Liu, S., L.G., et al. (2014) Identification for the Longmaxi Mud Shale Reservoir in the Jiaoshiba Area, Sichuan Basin. Natural Gas Industry, 34, 37-41.

[11] Guo, X.S., Hu, D.F., Li, Y.P., et al. (2014) Geological Features and Reservoiring Mode of Shale Gas Reservoirs in Longmaxi Formation of the Jiaoshiba Area. Acta Geologica Sinica (English Edition), 88, 1801-1840.

[12] Sheng, G.X. (2014) Enrichment Mechanism and Exploration Technology of the Shale gAs in Fuling Jialshiba Region. Science Press, Beijing.

[13] Zhang, C.M., Zhang, W.S. and Guo, Y.H. (2012) Sendinmentary Environment and Its Effect on Hydrocarbon Source Rocks of Longmaxi Formation in Southeast Sichuan and Northern Guizhou. Earth Science Frontiers, 19, 136-145.

[14] Guo, T.L., Li, Y.P. and Wei, Z.H. (2011) Reservoir-Forming Conditions of Shale Gas in Ziliujing Formation of Yuanba Area in Sichuan Basin. Natural Gas Geoscience, 22, 1-7.

[15] Liu, S.G., Ran, B., Guo, T.L., et al. (2014) Lower Palaeozoicorganic-Matter-Rich Black Shale in the Sichuan Basin and Its Periphery: From Oil-Prone Source Rock to Gas-Producing Shale Reservoir. Science Press, Beijing.

[16] Guo, T.L. (2015) Characteristics and Discovery of Fuling Shale Gas Field and Its Enlightenment and Thinking. Earth Science Frontiers, 23, 1-15.

[17] Zou, C.N., Zhang, G.S., Yang, Z., et al. (2013) Geological Concepts, Characteristics, Resource Potential and Key Techniques of Unconventional Hydrocarbon: On Unconventional Petroleum Geology. Petroleum Exploration and Development, 40, 385-399.

[18] Zhang, J.C., Jiang, S.L., Tang, X., et al. (2009) Accumulation Types and Resources Characteristics of Shale Gas in China. Natural Gas Industry, 29, 109-114.

[19] Li, X.J., Hu, S.Y. and Cheng, K.M. (2007) The Suggestion from the Exploration and Production of Fractured ShaleGas in North America. Petroleum Exploration and Development, 34, 392-400. 